\title{
Etnografen Werner Jacobsen og Det kongelige Bibliotek
}

af forskningsbibliotekar, mag.art. Frede Møller-Kristensen

Navnet Werner Jacobsen giver mange mennesker associationer i retning af arkæologi og etnografi. Man sætter uvilkårligt Werner Jacobsen (1914-1979) i forbindelse med museumsverdenen.

Det er kendt for mange, at han har indsamlet og hjembragt værdifulde samlinger af etnografisk materiale til Nationalmuseet og Forhistorisk Museum på Moesgaard. Det er sikkert kun de færreste, der ved, at Werner Jacobsen også har haft betydning for Det kongelige Biblioteks samlinger.

Werner Jacobsen tilbragte en stor del af sin tilværelse med ophold og studier i det fremmede. Allerede fra hans tidlige ungdom havde de asiatiske kulturer en dragende magt over ham. Sammen med filologen Kaare Grønbech deltog han som arkæolog i den 2. danske centralasiatiske ekspedition 1938-1939 til Indre Mongoli under ledelse af etnografen Henning HaslundChristensen.

Efter 2. Verdenskrig tog Werner Jacobsen på en privat ekspedition til Indien, hvor han blandt andet opholdt sig hos Toda-stammen i Sydindien. Med st $\varnothing$ tte fra et dansk ekspeditionsfond begav han sig i 1950 atter til Asien med halvandet års feltstudier som mål. Det blev imidlertid ikke til halvandet års feltstudier - men til en eventyrlig studierejse, der varede i ni et halvt år. Werner Jacobsen blev flere gange meldt savnet, men han dukkede altid op igen. Rejsen endte i Nepal, hvor han opholdt sig 1957-1959.

Efter hjemkomsten fra denne rejse begyndte en ny epoke i Werner Jacobsens liv. Han blev fast tilknyttet Nationalmuseet. I 1961 blev han museumsinspektør i Etnografisk Samling og i 1963 leder af Nationalmuseets Oplysningsafdeling. Den publikumsrettede virksomhed som leder af Oplysningsafdelingen optog Werner Jacobsen stærkt. Han blev blandt andet ophavsmand til de populære udstillinger i Brede. 
Werner Jacobsen nærede altid stærke følelser for de folk, han levede iblandt på sine rejser. Hans indlevelse i deres sæder og skikke var intens. Han var personligt betaget af den indiske tankeverden. Buddhismen stod i særlig grad hans hjerte nær. Dette gav sig synligt udslag i udstillingen Buddhas Veje (1970) - en udstilling, han lagde hele sin sjæl i. Det er måske den mest skattede af Nationalmuseets Brede-udstillinger.

Under sit ophold i Nepal i slutningen af 50'erne blev Werner Jacobsen for alvor klar over, at det - ud over indsamlingen af egentlige museumsgenstande - var af betydning også at indsamle og opkøbe skrevne og trykte kulturmindesmærker.

I sommeren 1958 tilbød han at indkøbe nepalisiske håndskrifter til Det kongelige Bibliotek. Orientalsk Afdeling var naturligvis yderst interesseret $\mathrm{i}$ at erhverve studiemateriale fra Nepal. Det var andre imidlertid også. Afdelingsleder Klaus Ferdinand, Forhistorisk Museum, citerer i et brev af 24.10. 1958 til Orientalsk Afdeling følgende udtalelse fra Werner Jacobsen: "For$\emptyset$ vrigt har jeg modtaget mange henvendelser fra flere amerikanske universiteter og biblioteker om at være dem behjælpelig med indkøb af MSS, så hvis KB ikke er interesseret, er det bedre, jeg hjælper dem, end at materialet forsvinder her, eller bliver utilgængeligt ved at ende som turistsouvenirs."

De udstationerede amerikanere og de mange souvenir-hungrende turister, der i disse år oversvømmede Nepal, gjorde det til en særdeles besværlig og bekostelig affære for Werner Jacobsen at erhverve nepalesiske håndskrifter: "Bortset fra ... er den største ulempe konkurrence fra amerikansk side. I forbindelse med den amerikanske hjælp til Nepal er der stationeret ca. 80 amerikanske familier her, hvoraf ikke få er ivrige antikvitets- og MS-jægere, og som på andre områder er det svært at klare sig over for den stærke \$. Desuden har det stadigt stigende antal af turister en uheldig indflydelse. De er alle ude efter souvenirs fra Nepal og illuminerede MSS er et yndet emne, og naturligvis har det ikke varet længe for antikvitetshandlerne at finde ud af, at det er en bedre forretning at "slagte" de illuminerede MSS, og sælge de ill. blade enkeltvis, hvilket har medført, at priserne paa komplette MSS er røget op i en pris, hvor jeg har svært ved at følge med. Paa den anden side er det jo til at græde over at se et godt gammelt MSS forsvinde paa den maade." (Brev til Orientalsk Afdeling 31.10.1958).

Amerikanerne nærer stor respekt for Werner Jacobsens evne til at udvælge de "rigtige" håndskrifter. Han er imidlertid selv meget beskeden med hensyn til sin egen viden på dette område: "Vanskeligheden er, at naar jeg her udviser den fjerneste interesse for en ting; men ikke samtidig omgaaende erhverver den, bliver den omgaaende taget til Amerikanerne, som naar de h $\varnothing$ rer, at jeg er interesseret omgaaende køber den til fantasipris. Om de blot 
vidste, hvor lidt jeg ved; men som det gamle indiske ordsprog siger: I de blindes land er den eenøjede Maharajah." (Brev til Orientalsk Afdeling 10. 6.1959).

Også i pengesager udviste Werner Jacobsen stor beskedenhed. Bibliotekets daværende leder, rigsbibliotekar Palle Birkelund, der med sin altid bevågne interesse for Orientalsk Afdeling fremskaffede de nødvendige midler til de nepalesiske håndskrift$\mathrm{k} \emptyset \mathrm{b}$, opfordrede gang på gang Werner Jacobsen til at beregne, hvad biblioteket skyldte ham i honorar for hans tidkrævende indsats. Først efter sin hjemkomst beregnede han sig et symbolsk honorar for sin indsats.

Med en ikke uberettiget stolthed afslutter Werner Jacobsen korrespondancen vedrørende indkøbene af håndskrifter fra Nepal med følgende ord: "Det springende punkt er nu at faa samlingen hjem; men vi maa haabe det gaar. Jeg tror, at Det kongelige Bibliotek vil blive meget tilfreds med denne nyerhvervelse, og jeg haaber, den vil tjene som grundlag for et værdifuldt studie. Den indeholder c. 25.000 beskrevne sider med mellem 6 og 700 polykrome miniaturer og tusindvis af tegninger og diagrammer, saa selvom det ikke altsammen er "guld", er det jo nok et værdifuldt studiemateriale." (Brev til Orientalsk Afdeling 15.8.1959).

Langt den overvejende del af Nepalsamlingens mere end to hundrede håndskrifter er skrevet på sanskrit eller nevari. Sprogene tibetansk og nepali er tilsammen repræsenteret med en halv snes numre.

Diagram over de vigtigste psykiske energicentre (cakra) i mennesket. De er efter tantrisk opfattelse medvirkende til at frigøre voldsomme psykiske krafter i forbindelse med en avanceret yoga-teknik. NEPAL 02 .

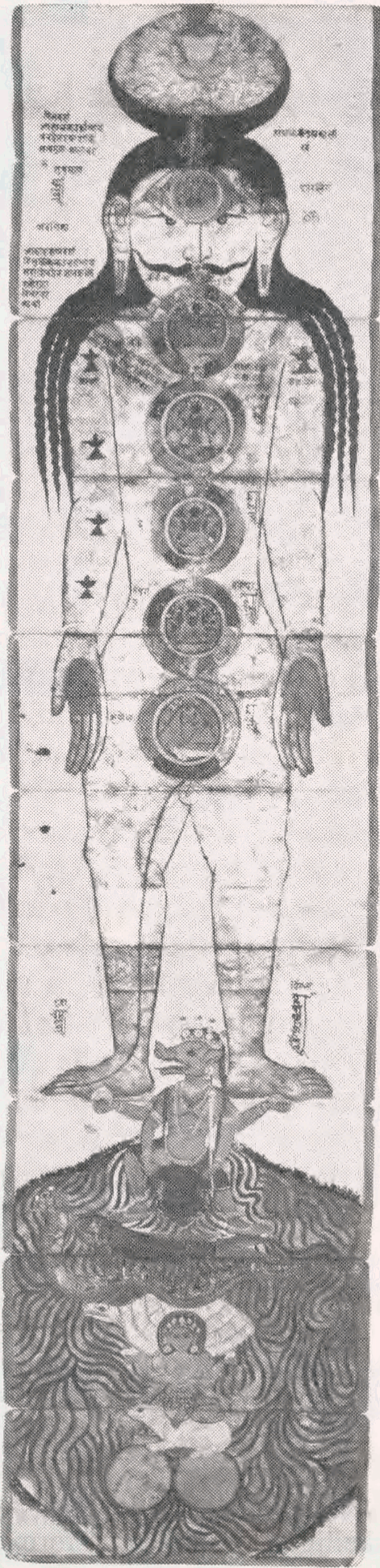


Sanskrit er ligesom dansk et indoeuropæisk sprog. Det tilhører den indoariske sprogstamme, der ved ariernes indvandring kom til Indien i det andet årtusinde for vor tidsregning. Sanskrit er de gamle inderes religiøse og litterære sprog. Det blev på et tidligt tidspunkt et lærd sprog - som latin i Europa. Det bruges den dag i dag både i skrift og tale i meget traditionsbevidste kredse.

Det sidste trin i den indo-ariske sprogudvikling er de ny-indiske sprog. Hertil hører nepali (nepalesisk) - Nepals officielle sprog - på linie med sprog som hindi, urdu og bengali.

Nevari er beslægtet med tibetansk. Det tilhører den tibeto-burmanske sprogfamilie. Trods nevarernes sproglige og racemæssige slægtskab med tibetanerne er det fra indiske side, at de har modtaget de stærkeste kulturpåvirkninger. Nevarernes kultur var i århundreder dominerende i Kathmandudalen, indtil de blev undertrykt af det såkaldte Rana-styre, der kom til magten omkring 1850. I forfølgelsesperioden frem til 1951 var nevari en tid ligefrem forbudt som skriftsprog.

Det er for en del mennesker en kendt sag, at sanskrit-studierne har dybe rødder i den danske lærdomshistorie. Det er næppe så velkendt, at nevari har været dyrket som studieobjekt i Danmark. Det er imidlertid en kendsgerning, at en foregangsmand inden for nevari-forskningen er dansker. Sprogforskeren Hans Jørgensen (1886-1954) fra Als gjorde studiet af nevari til sin livsopgave. Han studerede orientalske sprog $\mathrm{i}$ Tyskland og var i en årrække tilknyttet Museum für Völkerkunde i Berlin. Senere drev han - for egne midler og med fondstøtte - sine studier dels på sin fædrene gård på Als og dels på Det kongelige Biblioteks læsesal.

Hans Jørgensen udgav to nevari-tekster. Det vigtigste resultat af hans forskning er utvivlsomt hans beskrivelse af nevari-sproget gennem en ordbog (1936) og en grammatik (1941), som blev udgivet af Videnskabernes Selskab. Hans Jørgensens publikationer havde en ikke ringe betydning for mange af de undertrykte nevarer. Det var en opmuntring for dem at vide, at en fjern vesterlænding beskæftigede sig med deres sprog og kultur.

Det kongelige Bibliotek havde stor interesse $\mathrm{i}$ at erhverve nevarihåndskrifter bl.a. på grund af det pionérarbejde, som Hans Jørgensen havde gjort.

Werner Jacobsen lagde meget arbejde i at opspore materiale fra netop dette sprogområde. Han indsamlede 83 håndskrifter på nevari til Orientalsk Afdeling.

Orientalsk Afdelings Nepal-samling kan anskues ud fra andre synsvinkler end den sproglige. Samlingen indeholder et rigt materiale til studiet af forskellige orientalske bogformer og de materialer, de er skrevet eller trykt på. 


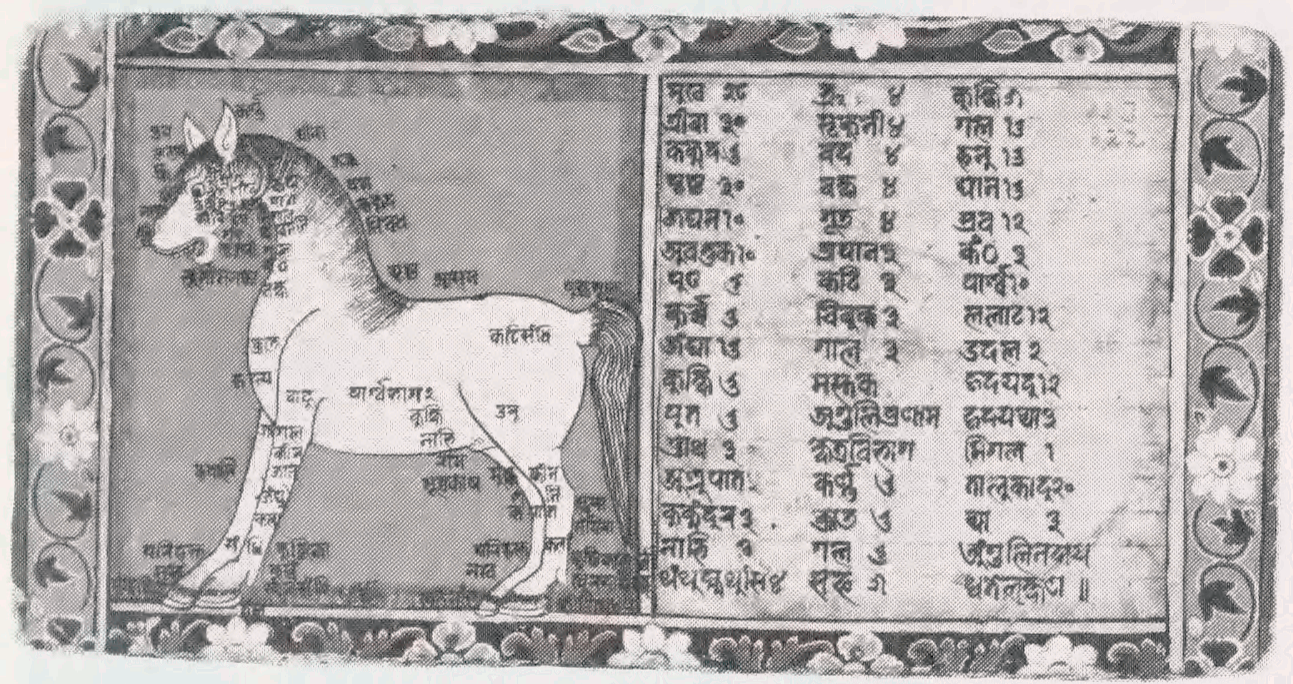

NEPAL 122 er en rigt illumineret foldebog, der handler om heste. Den ledsagende tekst er på nevari.

Bark, palmeblade og mange forskellige papirtyper er repræsenteret i Nepal-samlingen.

Bark er blevet anvendt mange steder i Orienten som skrivemateriale. NEPAL 123 er et nepalesisk bark-håndskrift. Til dette håndskrift er der anvendt inderbarken fra det såkaldte ørnetræ.

Palmebladet er det mest benyttede skrivemateriale i Syd- og Sydøstasien inden anvendelsen af papiret blev almindeligt i disse områder. NEPAL 173, der er fra 1100-tallet, hører til de ældst bevarede palmebladshåndskrifter fra Nepal. Det indeholder en buddhistisk tekst skrevet med bambuspen på hamrede, slebne palmeblade. Blækket består af sod udrevet med en plantegummi.

Det er karakteristisk for Nordindien, at man skriver med pen og blæk på palmeblade. I Sydindien, på Sri Lanka og i Sydøstasien indridser man skrifttegnene med en spids stylus. For at fremme læsbarheden foretages en indgnidning med pulveriseret trækul og olie. Ved denne proces udfylder sværten de indridsede skrifttegn.

Alle faser i udviklingen af den "indiske bog" kan belyses ved eksempler fra Nepal-samlingen.

Den indiske kulturs nære forbindelse med de omliggende kulturer, for eksempel den nepalesiske og tibetanske, afspejler sig også på det bogmæssige område.

Grundlaget for den klassiske indiske bog er palmebladshåndskriftet. De bearbejdede og beskrevne palmeblade holdes sammen med hjælp af snore, 


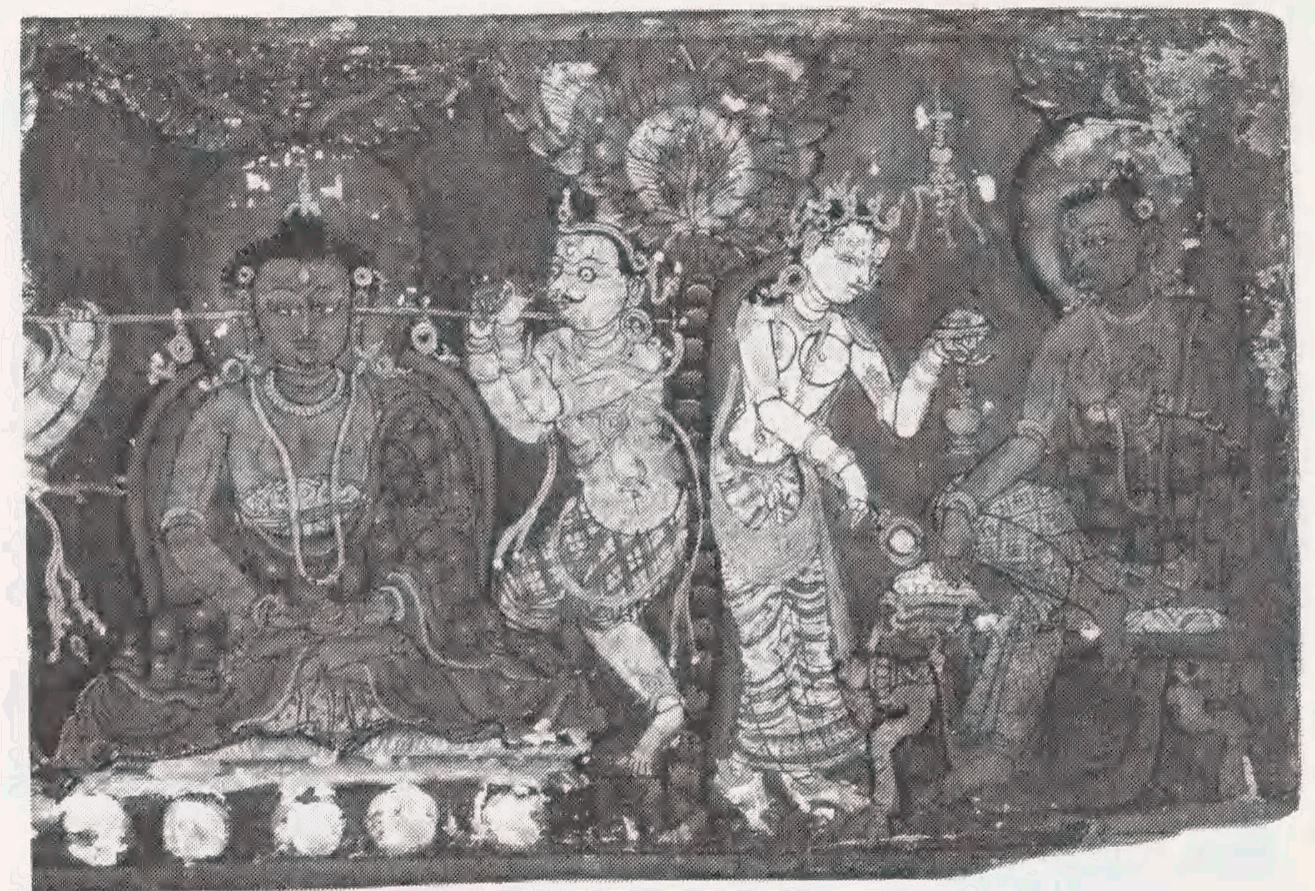

De to dækplader til NEPAL 152 har meget smukke malerier, der gengiver vigtige episoder i Buddhas liv.

der trækkes igennem huller i bladene. Som regel beskyttes palmebladshåndskriftet af to dækplader af træ, der fungerer som bind. Da papiret fra 1200-tallet langsomt vandt udbredelse i Indien, blev palmebladets karakteristiske aflange form normgivende for håndskrifter på papir. Snorene til at holde bladene sammen blev efterhånden opgivet. Dels ødelægger snorene hurtigt papiret og dels er de overflødige, fordi papirer ikke er så "levende" som de glatpolerede palmeblade. Papirhåndskriftet kan ligesom palmebladshåndskriftet være forsynet med dækplader af træ.

Dækpladerne er af vidt forskellig art. Det kan dreje sig om simple træstykker eller om rene kunstværker, hvad angår udskæring og dekorering. De to dækplader til NEPAL 152 - et buddhistisk håndskrift fra 1500-tallet - har på siderne mod håndskriftet meget smukke malerier, der gengiver vigtige episoder i Buddhas liv. På ydersiderne er de dekoreret med stiliserede blomstermotiver.

NEPAL 75 har et usædvanligt træbind. Den øverste dækplade er formet som en sarkofag. Det midterste felt med tre cirkelrunde rosetter udg $\varnothing \mathrm{r}$ et skjult skydelåg, der dækker over to små rum.

En anden indisk bogtype er foldebogen. Den består af ét langt stykke papir, der er foldet som en vifte. Den udviser i sammenfoldet stand også palmebladets aflange form. 
Det er tydeligt, at palmebladet har dannet grundlag for de senere papirhåndskrifters ydre form. Venerationen for den gamle bog gælder dog ikke den ydre form alene. Der findes håndskrifter på papir, hvor de områder, der på palmebladene ville være forsynet med et hul til snoren, er markeret med røde prikker eller cirkler. Her er ikke blot tale om en håndværksmæssig veneration for den oprindelige bogform. Religiøse grunde har sikkert spillet ind. St $\varnothing$ rstedelen af de tekster, der blev nedskrevet, havde et religiøst indhold. Det ville være helligbrøde, hvis såvel den afskrevne tekst som bogens ydre form ikke svarede til originalen.

Betragter vi Orientalsk Afdelings Nepal-samling fra endnu en synsvinkel, når vi frem til håndskrifternes indhold - til de kategorier af tekster, der er repræsenteret i samlingen.

Tekster af religiøs art er rigest repræsenteret i Nepal-samlingen.

Det drejer sig om tekster, der på en eller anden måde belyser sider af de to store verdensreligioner: hinduismen og buddhismen.

Hinduismen, der alene i Indien har omkring $85 \%$ af dets mere end 600 millioner mennesker som tilhængere, er vaskelig at definere. Den kan fremvise mange fremtrædende religiøse personligheder, men ingen grundlægger. Den har et hav af hellige skrifter, men ingen "bibel". Hinduismen har heller ingen trosbekendelse. Der findes ingen ritualer, der er fælles for alle dens tilhængere. I hinduismens brede favn kan vidt forskellige former for gudsdyrkelse rummes. Man kan benægte guds eksistens, og alligevel kan man være hindu.

Nehru forsøger at forklare hinduismen med følgende ord: "Det er næppe muligt at definere den eller endog definitivt at sige, om den er en religion eller ikke i ordet almindelige betydning. I den nuværende form - ligesom det var tilfældet $\mathrm{i}$ tidligere tider - favner den mange former for tro og religiøs praksis, fra de højeste til de laveste, ofte former der modsiger hinanden."

I Nepal finder vi både Vishnu-tilhængere og Siva-tilhængere. Vishnuismen og sivaismen er de to retninger, der i særlig grad har præget hinduismens udvikling op til nutiden.

Werner Jacobsen lagde vægt på at indsamle tekster, der var aktuelle i den daglige religiøse praksis. Ritualteksterne udgør derfor en overvejende del af de hinduistiske tekster i samlingen.

Han købte dog også nogle af hinduismens klassiske værker.

Et af hinduismens mest udbredte skrifter er Bhagavadgita (NEPAL 07). Det er i oversættelser fra sanskrit kendt i vide kredse - også uden for de hinduistiske. Bhagavadgita ('Den Ophøjedes Sang') er et religiøst læredigt, der indgår i indernes vældige national-epos Mahabharata. Hovedhandlingen 
i Mahabharata er beretningen om en strid, der udkæmpes mellem to grene af samme slægt.

Handlingen i Bhagavadgita udspilles lige inden det store slag skal begynde. Begge hære er opstillet over for hinanden. En af heltene betragter fra sin stridsvogn de mange venner og slægtninge i modstanderens rækker. Han bliver betænkelig. Han kan ikke kæmpe. Hans vognstyrer Krishna (en inkarnation af guden Vishnu), belærer ham om, at det er hans pligt som kriger at kæmpe. Ethvert menneske skal udføre de handlinger, som hans stilling i samfundet kræver. Det er denne belæring om pligtens betydning, der er hovedemnet i Bhagavadgita.

Buddhismen voksede frem i Indien omkring fem hundrede år før vor tidsregning. Ikke længe efter Buddhas død opstod der splid blandt hans tilhængere, og der dannedes snart flere forskellige skoler. En enkelt af de ældste skoler lever videre i dag i buddhismen på Sri Lanka og i Sydøstasien.

Ved vor tidsregnings begyndelse spirer en ny retning frem inden for buddhismen: mahayana ('det store fartøj'). Tilhængere af mahayana mener, at de gamle skolers religiøse idealer kun kan efterleves af et fåtal. Mahayana-tilhængerne kan derimod tilbyde en lære, der i højere grad kan tilfredsstille de buddhistiske lægfolks religiøse behov. De hævder endvidere, at deres læretekster (sutra), der er blevet til mellem 100- og 500-tallet, er forkyndt af Buddha selv. Det er mahayana der ligger til grund for buddhismen i Nepal, og samlingen indeholder adskillige mahayana-sutraer.

Mange af de religiøse tekster i Nepal-samlingen er tantriske. Omkring midten af det første årtusinde efter vor tidsregning gør de såkaldte tantriske retninger sig stærkt gældende inden for både hinduismen og buddhismen. Disse retninger benævnes tantrisme efter deres religiøse litteratur (tantra). Tantra-værkerne behandler de væsentligste elementer i disse systemers lære: mandala, en mystisk cirkel eller et diagram, der danner en ramme om de forskellige guders åndelige og kosmiske aktiviteter. Mantra omfatter formler og mystiske stavelser, der symboliserer guder og kræfter. Ved gentagne gange at rette en særlig mantra til en bestemt guddom kan en indviet komme i mystisk kontakt med vedkommende guddom. Mantraerne bliver mere effektive, hvis fremsigelsen af dem ledsages af symbolske håndbevægelser ( $m u$ dra).

Kundalini betegner efter tantrisk opfattelse et yderst virkningsfuldt energicentrum i mennesket. Det opfattes symbolsk som en sammenrullet slange, der befinder sig ved den nederste del af rygsøjlen.

Det er for mangen en yogin højdepunktet at vække kundalinien. Dette lader sig kun gøre gennem en meget avanceret yoga-teknik. NEPAL 02 viser et diagram over de vigtigste energi-centre (cakra), der er beliggende på en 


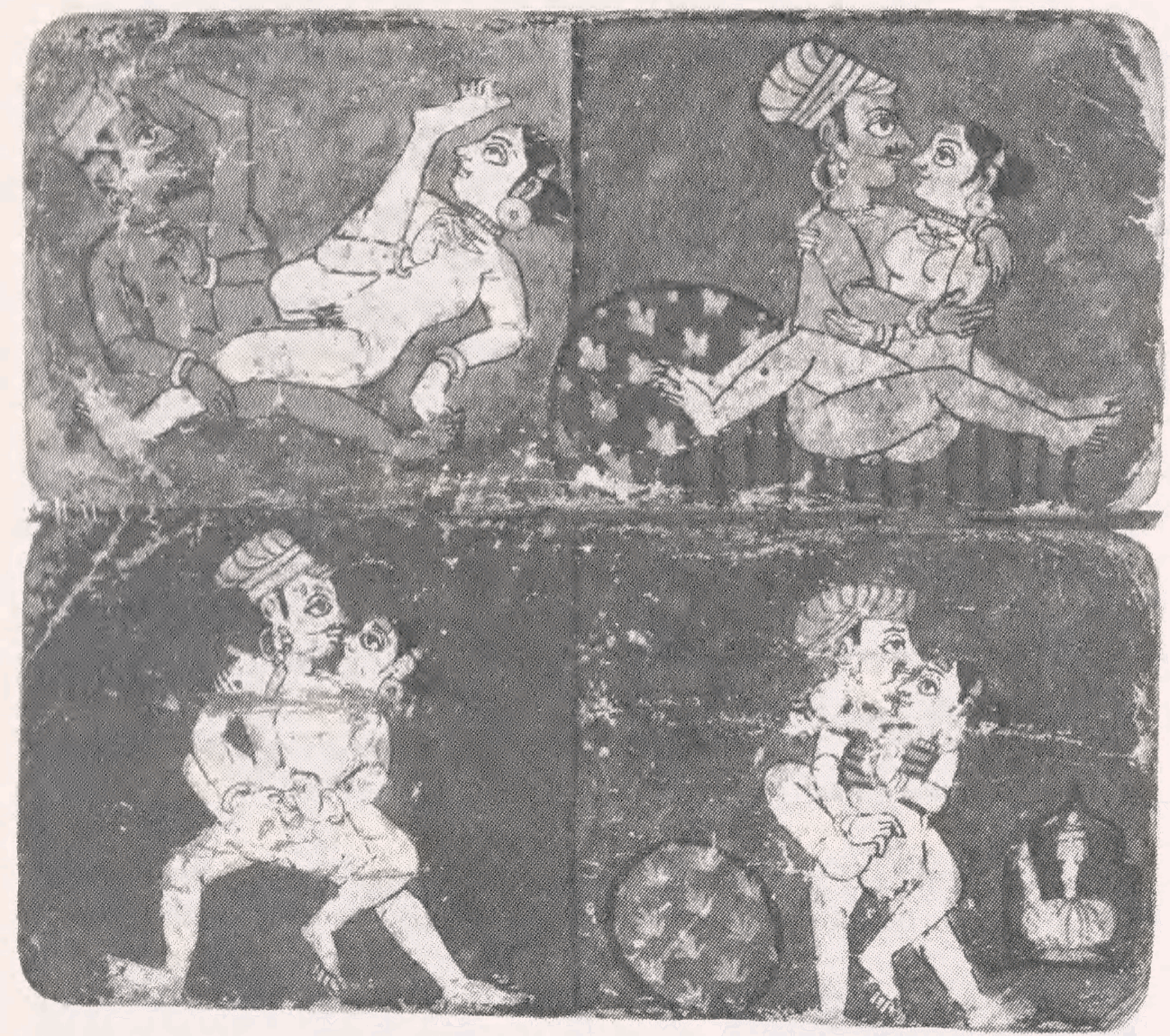

Motiver fra en foldebog, der i folkelig stil blandt andet viser 40 forskellige former for samleje.
NEPAL 49. linie fra den nederste del af rygsøjlen til hovedets top. Når kundalinien vækkes, stiger den gennem disse psykiske energicentre, idet den frigør voldsomme kræfter.

Et vigtigt element i tantrismen er det erotiske. I tantrisk mytologi forsynes guder og buddhaer efterhånden med kvindelige partnere. I kunsten fremtræder de i samlejestillinger. Gudinden opfattes som gudens aktive element, hun er gudens styrke og energi (sakti). I yderliggående tantriske retninger indgår sexorgier og blodige dyreofringer som rituelle elementer.

En del håndskrifter $\mathrm{i}$ Nepal-samlingen beskæftiger sig med tantrisk magi. De indeholder utallige opskrifter $\mathrm{p} a ̊$, hvorledes man blandt andet kan forhekse sine fjender og ombringe en person ved hjælp af magiske midler.

Flere af disse magiske håndskrifter er overstænket med blod og fjer fra offerdyrene - at anvende et sådant håndskrift under ritualerne har utvivlsomt efter udøverens mening haft en fremmende virkning på det forventede resultat. 
Gruppen af håndskrifter, der omfatter ikke-religiøs litteratur, spænder emnemæssigt vidt: lige fra faglig-teknisk litteratur til skønlitterære værker. Eksempelvis kan nævnes håndskrifter, der omhandler: grammatik, leksikografi, historie, astrologi, drømmetydning og hippologi.

Eksempler på klassisk fortællings- og skønlitteratur på sanskrit er: NEPAL 174 (Sukasaptati) og NEPAL 36 (Gitagovinda).

Sukasaptati ('Papegøjens 70 Fortællinger') er en berømt eventyrsamling fra det gamle Indien. Fortælleren i Sukasaptati er en papegøje. Den fortæller hver aften i 70 dage en ung kvinde, hvis mand er på rejse, en historie. Den unge kvinde bliver hver gang så optaget af papegøjens fortælling, at hun ikke når til stævnemøde med sin elsker.

Gitagovinda, et digt fra 1100-tallet, er skrevet af den bengalske hofdigter Jayadeva. Digtets hovedpersoner er den guddommelige helt Krishna og hyrdepigen Radha. Det fortælles, at Krishna voksede op blandt hyrder. Han havde mange kærlighedsaffærer med hyrdepigerne, men den smukke Radha var hans foretrukne. Digtet skildrer i smukke strofer Krishnas og Radhas kærlighedsforhold. Gitagovinda kan opfattes både som et kærlighedsdigt og som et stykke religiøs mystik.

Under sit ophold i Nepal blev Werner Jacobsen stærkt betaget af de nepalesiske bloktryk. De fremviser en folkekunst, der er baseret på ældgamle traditioner.

Nepaleserne anvender bloktrykkene i forbindelse med bestemte religiøse fester og ceremonier.

I 1959 fortalte Werner Jacobsen om disse bloktryk og deres anvendelse i en artikel i KUML (Årbog for jysk arkæologisk Sekskab). Artiklen blev senere til et imponerende bogværk: Bloktryk fra Nepal. Bogen udkom i 1966 i 67 nummererede eksemplarer, illustreret med originale farvelagte bloktryk.

Samtidig med udgivelsen af dette pragtværk forærede Werner Jacobsen Orientalsk Afdeling en samling på 45 nepalesiske bloktryk. De er opklæbet på håndgjort papir og indbundet i samme udstyr som bogværket.

Orientalsk Afdelings Nepal-samling indeholder et alsidigt studiemateriale. Derfor benyttes det i mange sammenhænge. For eksempel har leder af konserveringsafdelingen på Forhistorisk Museum, Moesgaard, Jesper Trier, i rigt mål gjort brug af samlingen til sin disputats om nepalesisk papir, Ancient Paper of Nepal, 1972.

Samlingen har endvidere bidraget med materiale til Brede-udstillingen Buddhas Veje (1970) og til udstillingen Kunst fra Himalaya på Sophienholm (1976). 
Werner Jacobsen satte stor pris på de omtalte dækplader til NEPAL 152 . Han bestemte, at et motiv herfra skulle pryde udstillingsplakaten til Buddhas Veje. I publikationen af samme navn som udstillingen er alle otte scener fra Buddhas liv gengivet.

Det kongelige Bibliotek har udsendt et postkort med episoden, hvor den onde ånd, Mara, frister Buddha med verdslig magt og rigdom for at afholde ham fra at forkynde sin lære.

Orientalsk Afdeling deltog med en stor del af Nepal-samlingen i en udstilling, der blev afholdt på Herning Kunstmuseum 9. marts -21. april 1991. Udstillingens titel var Asiatiske Akkorder - med etnografen Werner Jacobsen $i$ Asien.

Størstedelen af materialet til udstillingen er genstande, der er hentet fra samlinger på Forhistorisk Museum, Moesgaard, hvor udstillingen gentages i løbet af foråret 1992.

Motiver fra ovennævnte dækplader smykkede også denne udstillings plakat og publikation.

\section{LITTERATUR}

JACOBSEN, WERNER: Nepalesiske bloktryk. (KUML - Årbog for jysk arkæologisk Selskab). Aarhus. 1959.

- $\quad$ Asiatiske akkorder. Kbh. 1965.

- Bloktryk fra Nepal. Kbh. 1966.

KRAG, ANNE HEDEAGER: Eventyrer og fornyer. Herning Folkeblad. 18.1.1989.

PAULY, ELSE: Hans Jörgensen: A Pioner in Nevari Studies. (Indologica Taurinensia, vol. 10. Torino. 1982.

- $\quad$ Alsingeren, dr.phil. Hans Jørgensen. (Sønderjysk Månedsskrift 1986:1).

TRIER, JESPER: Ancient Paper of Nepal. Kbh. 1972. 
